\title{
Relationship between fiscal instruments and investments of industrial SMEs and LEs in Poland
}

\section{Introduction}

The European Union countries, including Poland, have supported investments of enterprises for many years. This is an important factor that influences Gross Domestic Product. However, enterprises are not a homogeneous group of entities. Small and medium-sized enterprises (SMEs) have significant contributions into employment, whereas large enterprises (LEs) introduce many innovations. Nevertheless, support for them is provided by both financially, like grants or subsidies and non-financial instruments (for example, technology parks). Fiscal instruments such as tax breaks or depreciation allowances belong to the first group; however, the effectiveness of these support instruments is still a subject of debate. Moreover, there is a dearth in the literature as to the relationship between fiscal instruments and investments in SMEs and LEs in Poland. This study seeks to address this gap by using statistical tools and trying to build an econometric model.

The paper is organized as follows: in Section 2 we scrutinize the findings of research that has already been published. Section 3 presents the research questions, the aim of the study, and the hypothesis. Section 4 describes how the data was collected, presents the process of statistical analysis, and attempts to build an econometric model. Section 5 shows the conclusions after the study.

\section{Literature review}

Most of the official reports in Poland about the impact of public policy on SMEs focus on grants (Pokorski, 2010, 2011) or microcredit funds (Analiza korzyści..., 2012). Many studies also concentrate on subsidies (Norman and Bager-Sjögren,

* AGH University of Science and Technology, Faculty of Management, Department of Economics, Finance and Environmental Management, e-mail: mwozniak@zarz.agh.edu.pl

** AGH University of Science and Technology, Faculty of Management, Department of Economics, Finance and Environmental Management, e-mail: rlisowsk@zarz.agh.edu.pl 
2010; Karafolas and Woźniak, 2014b; Peszko, 2014), venture capital (Denis, 2004; Bertoni, Colombo and Grilli, 2011), loan guarantees (Riding and Haines, 2001; Boocock and Shariff, 2005; Karafolas and Woźniak, 2014a) or microcredits (Karlan, 2007; Newman, Schwarz, Borgia, 2014).

As fiscal instruments belong to tax expenditures, many authors have criticized their usefulness (Zbroińska, 2006; Wyszkowski, 2010; Goolsbee, 1997; Mintz, 1990). However, authors who research the impact of tax incentives on SMEs concentrate mainly on research and development activities (R\&D). Banghan and Mohnen (2009) evaluated the effectiveness of R\&D tax incentives in small and large companies in Quebec and concluded that there was a deadweight loss, particularly for large enterprises. Ortega et al. (2009) believes that R\&D policy (including fiscal incentives) ought to be complemented with other policies favoring SMEs. Hendricks et al. (1997) made research on the potential impact of business taxation on SMEs in Canada using a longitudinal database. The findings reveal that the role of the small business deduction that was a fiscal incentive program as a source of financing growth was restricted to a small fraction of Canadiancontrolled private companies. However, the subject of tax incentives is sometimes a part of wider works examining the impact of public policy on SMEs in countries like (for instance) Poland (Matejun, 2003, 2005; Wach, 2008; Woźniak, 2012), Malesia (Muhammad et al., 2010), or China (Chen, 2006).

Many SMEs regard fiscal requirements as very significant barriers of development. One of the main problems is that tax law is very complicated. In addition, tax offices present different interpretations of tax law. In connection to the above, a Polish entrepreneur has to make about 40 payments at constitute $40 \%$ of his profits and takes approximately 420 hours per year (Woźniak, 2012). Nevertheless, the survey made by Woźniak (2011) revealed that SMEs find fiscal incentives as very important for their development. Moreover, most of them regard tax breaks for investments as justified (Zbroinska, 2006). However, some authors argue the reason could be that SMEs just want to lower their tax liabilities and not focus on their efficiency (Zbroińska, 2006). In connection to the above, Gołębiowski (2009) proposes decreasing the tax level and eliminating other tax incentives.

Nevertheless, tax incentives seem to be more important for SMEs, as they face many more constraints in accessing bank loans than large enterprises (Wach, 2008; Woźniak, 2007; Duda, 2013). Therefore, there is a need to cover their comprehensive support system, including fiscal support instruments that should correspond to the needs of Polish SMEs (Woźniak, 2012).

Development of an enterprise is connected with investments. There are many factors that could influence them. According to the literature (Begg et al., 2005; Krugman and Wells, 2012), these could be consumer confidence, economic indi- 
Relationship between fiscal instruments and investments...

cators in the industry, interest rates on loans, the situation on the credit market, gross household savings, and the price of production goods.

There are important studies regarding the tax impact on enterprises that make a distinct contribution to the literature. However, most of them concentrate only on SMEs. Moreover, there is a shortage of similar research for Polish enterprises.

\section{Starting point}

The value of tax expenditures for enterprises in Poland has been increasing for many years (Preferencje podatkowe..., 2014) and nowadays is similar to the worth of microloans or loan guarantees (Raport o pomocy..., 2015, Mikropożyczki..., 2013). Taking also the literature review into consideration, the following questions have not been answered as of yet:

- Is there a relationship between fiscal incentives and the investments of industrial micro, small, and medium-sized companies, and large enterprises in Poland?

- If there is such relationship, is it stronger for industrial micro, small, and medium-sized companies than for large enterprises in Poland?

- If there is such relationship, is it stronger than other factors that are related to the investments of enterprises?

In connection to the above questions, the aim of this study is to analyze the relationship of fiscal support instruments and level of investments of industrial micro, small and medium-sized enterprises as compared to large companies in Poland during the years 2006-2014.

Based on the literature review, the following hypotheses were proposed:

H1. There is a relationship between fiscal incentives and the investments of industrial micro, small, medium-sized companies, and large enterprises in Poland.

H2. This relationship is stronger for industrial micro, small, and medium-sized companies than large enterprises in Poland.

H3. The relationship between other factors that are related to the investments is stronger than for the fiscal incentives, and the investments of industrial micro, small, and medium-sized companies as well as large enterprises in Poland.

The authors decided to apply mainly statistical analysis, both basic as well as multidimensional. It allows us to analyze the empirical data, interpret the results, and present our conclusions. 


\section{Analysis}

\subsection{Collecting data}

In order to test the hypotheses, the authors collected and analyzed statistical data. The next stages of the research were as follows:

- collect statistical data that could potentially be useful in the analysis - the authors used suggestions of literature as well as their own experiences;

- simple statistical analysis in the form of calculating the Pearson correlation coefficients - this stage was to detect associations between the analyzed variables and discard the useless variables;

- the advanced (multivariate) statistical analysis in the form of cluster analysis and multidimensional scaling - this stage was to detect more-complex relationships between variables and to select independent variables for the econometric model;

- an attempt to construct an econometric model based on a multiple regression - as a model that shows the specific impact of several variables on the level of investments of companies.

First, the authors identified the tax expenditures in the area of economics in Poland. Then, the fiscal incentives that aim is to support the investments of enterprises were chosen. They are presented in Table 1.

Table 1

Fiscal incentives that support investments of enterprises in Poland

\begin{tabular}{|l|c|}
\hline \multicolumn{1}{|c|}{ Type of tax } & Name of incentive \\
\hline \multirow{4}{*}{$\begin{array}{l}\text { Personal Income Tax } \\
\text { (PIT) }\end{array}$} & special economic zones \\
\cline { 2 - 2 } & one-time depreciation \\
\cline { 2 - 2 } & allowances of expenses for acquisitions of new technology \\
\cline { 2 - 2 } & settlement of losses from previous years \\
\cline { 2 - 2 } & decreasing the maximum tax level \\
\hline \multirow{4}{*}{$\begin{array}{l}\text { Corporate Invome Tax } \\
\text { (CIT) }\end{array}$} & decreasing the minimum tax level \\
\cline { 2 - 2 } & special economic zones \\
\cline { 2 - 2 } & allowances of expenses for acquisitionof new technology \\
\cline { 2 - 2 } & settlement of losses from previous years \\
\cline { 2 - 2 } & allowances for capital expenditure \\
\cline { 2 - 2 } & exemptions for companies with foreign shareholders \\
\cline { 2 - 2 } & decreasing tax level \\
\hline
\end{tabular}


After that, the following data for the years 2006-2014 was collected:

1) The level of investment in industry in the private sector for micro-, small-, medium-sized companies and large enterprises in Poland (Rocznik statystyczny przemysłu, 2007-2014) - dependent variables;

Data concern economic entities conducting activity, in accordance with the Polish Classification of Activities - PKD 2007, within the scope of the following sections: "Mining and quarrying," "Manufacturing," "Electricity, gas steam and air conditioning supply," as well as "Water supply; sewerage, waste management, and remediation activities". In the scope of production of products data concern entities manufacturing industrial products, irrespective of their kind of activity classified according to PKD 2007 (Rocznik statystyczny przemysłu, 2007-2014).

"The term economic entities is understood as entities conducting economic activity (production and services) on their own account in order to earn a profit" (Rocznik statystyczny przemysłu, 2014, p. 29).

2) The worth of fiscal instruments whose aim was to support the investments of enterprises and tax levels for Personal Income Tax (PIT) and Corporate Income Tax (CIT) (Ministerstwo Finansów, http://www.finanse.mf.gov.pl/cit/ statystyki, http://www.finanse.mf.gov.pl/pit/statystyki) - potentially independent variables.

3) Other factors that should influence the level of the investments of enterprises:

- potentially independent variables;

- indicators of consumer confidence (Główny Urząd Statystyczny, http://stat. gov.pl/obszary-tematyczne/koniunktura/):

- indicator of demand forecasts;

- economic indicators in the industry (Narodowy Bank Polski, http://www. nbp.pl/home.aspx?c=/ascx/koniunktura_prezentacja.ascx):

- indicator of economic outlook forecasts of enterprises,

- indicator of new orders,

- indicator of production forecasts,

- indicator of new orders,

- indicator of new investments;

- interest rates on loans (Narodowy Bank Polski, http://www.nbp.pl/home. aspx?f=/statystyka/pieniezna_i_bankowa/oprocentowanie_n.html);

- NBP surveys on the situation in the credit market (Narodowy Bank Polski, http://www.nbp.pl/home.aspx?f=/systemfinansowy/kredytowy.html);

- gross household savings ("Rocznik statystyczny Rzeczpospolitej Polskiej" 2007-2014);

- Production Price Index (PPI) (Główny Urząd Statystyczny, http://stat.gov. pl/obszary-tematyczne/ceny-handel/ceny/). 
This allowed us to choose 37 variables, among which 35 could be explanatory variables that describe the change in the level of investments in the industry.

The variables denominated in PLN are given in nominal values. However, it can be assumed that the impacts of price changes on these variables are similar. These variables do not require a conversion on real values. Any conversion of the same inflation rates would not change the correlation values and the results of the model.

As far as the variables like consumer confidence, economic outlook, or surveys on the situation in the credit market are concerned, it can be assumed that the respondents know the overall economic outlook of Poland so they take into account the inflation rate. Any conversion of the nominal values could cause a distortion of correlation indicators.

\subsection{Statistical analysis}

First, the easiest stage of the analysis was to calculate the correlation coefficients of Pearson. Table 2 presents the significant correlations.

The results indicate that the level of investments in micro- and small-sized enterprises (MSEs) is significantly associated with the following variables:

1) Fiscal incentives under PIT:

- allowances of expenses for acquisitions of new technology (WNT-PIT),

- settlement of losses from previous years according to the general, progressive tax scale (SLU-PIT),

- settlement of losses from previous years according to the flat tax (SLU-PIT19).

2) Fiscal incentives under CIT:

- exemptions for companies with foreign shareholders (ZUZ-CIT),

- special economic zones (SSE-CIT),

- settlement of losses from previous years (SLU-CIT),

- allowances of expenses for acquisitions of new technology (WNT-CIT).

3) Other factors: indicator of new orders (WNZ).

The level of investment in medium enterprises (MEs) is associated with:

1) Fiscal incentives under PIT:

- allowances of expenses for acquisitions of new technology (WNT-PIT),

- settlement of losses from previous years according to the general, progressive tax scale (SLU-PIT),

- settlement of losses from previous years according to the flat tax (SLU-PIT19). 
2) Fiscal incentives under CIT:

- special economic zones (SSE-CIT),

- settlement of losses from previous years (SLU-CIT),

- allowances of expenses for acquisitions of new technology (WNT-CIT).

3) Other factors:

- indicator of economic outlook forecasts of enterprises (WPSE),

- indicator of demand forecasts (WPP),

- indicator of new orders (WNZ),

- indicator of production forecasts (WPPr).

Table 2

Significant correlations between the level of investment in the industry and the potential explanatory variables

\begin{tabular}{|c|c|c|c|c|c|}
\hline Variables & $\begin{array}{l}\text { Investments } \\
\text { of MSEs }\end{array}$ & Variables & $\begin{array}{l}\text { Investments } \\
\text { of MEs }\end{array}$ & Variables & $\begin{array}{l}\text { Investments } \\
\text { of LEs }\end{array}$ \\
\hline WNT-PIT & 0,855794 & SLU-PIT & 0,799133 & SLU-PIT & 0,674747 \\
\hline SLU-PIT & 0,919978 & SLU-PIT19 & 0,758023 & SLU-PIT19 & 0,717128 \\
\hline SLU-PIT19 & 0,893376 & SSE-CIT & 0,840132 & SSE-CIT & 0,781529 \\
\hline ZUZ-CIT & $-0,755401$ & SLU-CIT & 0,709321 & WPSE & $-0,744490$ \\
\hline SSE-CIT & 0,922358 & WNT-CIT & 0,714419 & WPP & $-0,803772$ \\
\hline SLU-CIT & 0,924018 & WPSE & $-0,763983$ & WNZ & $-0,765059$ \\
\hline WNT-CIT & 0,819026 & WPP & $-0,730127$ & WPPr & $-0,749511$ \\
\hline WNZ & $-0,674568$ & WNZ & $-0,748817$ & WNI & $-0,690088$ \\
\hline WNT-PIT & 0,751721 & WPPr & $-0,685153$ & & \\
\hline
\end{tabular}

* MSEs - micro- and small-sized enterprises, MEs - medium enterprises, LEs - large enterprises. Level of significance: $p=0,05$

Finally, the level of investment in large enterprises is associated with:

1) Fiscal incentives under PIT:

- settlement of losses from previous years according to the general, progressive tax scale (SLU-PIT),

- settlement of losses from previous years according to the flat tax (SLU-PIT19).

2) Fiscal incentives under CIT: special economic zones (SSE-CIT). 
3) Other factors:

- indicator of economic outlook forecasts of enterprises (WPSE),

- indicator of demand forecasts (WPP),

- indicator of new orders (WNZ),

- indicator of production forecasts (WPPr),

- indicator of new investments (WNI).

The analysis of correlation coefficients allows for the following conclusions:

- three fiscal incentives: SLU-PIT, SLU-PIT19, and SSE-CIT are correlated with the investments of both MSEs, MEs, and LEs;

- the correlation coefficient is higher for MSEs than for MEs and LEs;

- the investments of MSEs, MEs, and LEs are also significantly correlated with each other;

- the relationship between investments of MSEs with ZUZ-CIT is negative, which probably stems from a smaller and smaller field of application of the tax exemption referred to in Article 23 of the law on companies with foreign participation (Dz.U. $1991 \mathrm{Nr} 60$, poz. 253), and this article was repealed in 1996;

- interesting fact is that the correlations between the levels of investment and both the indicators of consumer confidence and business prosperity in the industry are negative. One may say that the expectations of consumers and producers are different from their decision about investments.

Although the calculated correlations are evidence of a significant relationship between dependent variables and some potential independent variables, one cannot formulate on this basis the decisive conclusions. The relationship between variables can be random, even if there is a cause-and-effect relationship; at this point, the authors could not state which variable is "a cause" or ,an effect." Correlation analysis does not provide a full basis for grouping the potential independent variables and assess their overall impact on the dependent variables. Therefore, it is possible (the hypothesis may be true), and it is necessary to continue advanced analysis. However, the authors could not state that some of the variables will not be useful in the construction of an econometric model (which is a normal statistical inference).

The next stage was a cluster analysis. This analysis is used to organize observed data (potential independent variables) in a meaningful structure or grouping the data (StatSoft, 2014). In order to form a vertical hierarchical tree, the method of Ward was chosen. This method is considered to be very efficient (Ward, 1963). As a unit of distance measure, 1-r Pearson's was used. After determining the upper limit of distance measure at 2 , a division into groups was received. This is shown in Figure 1. 


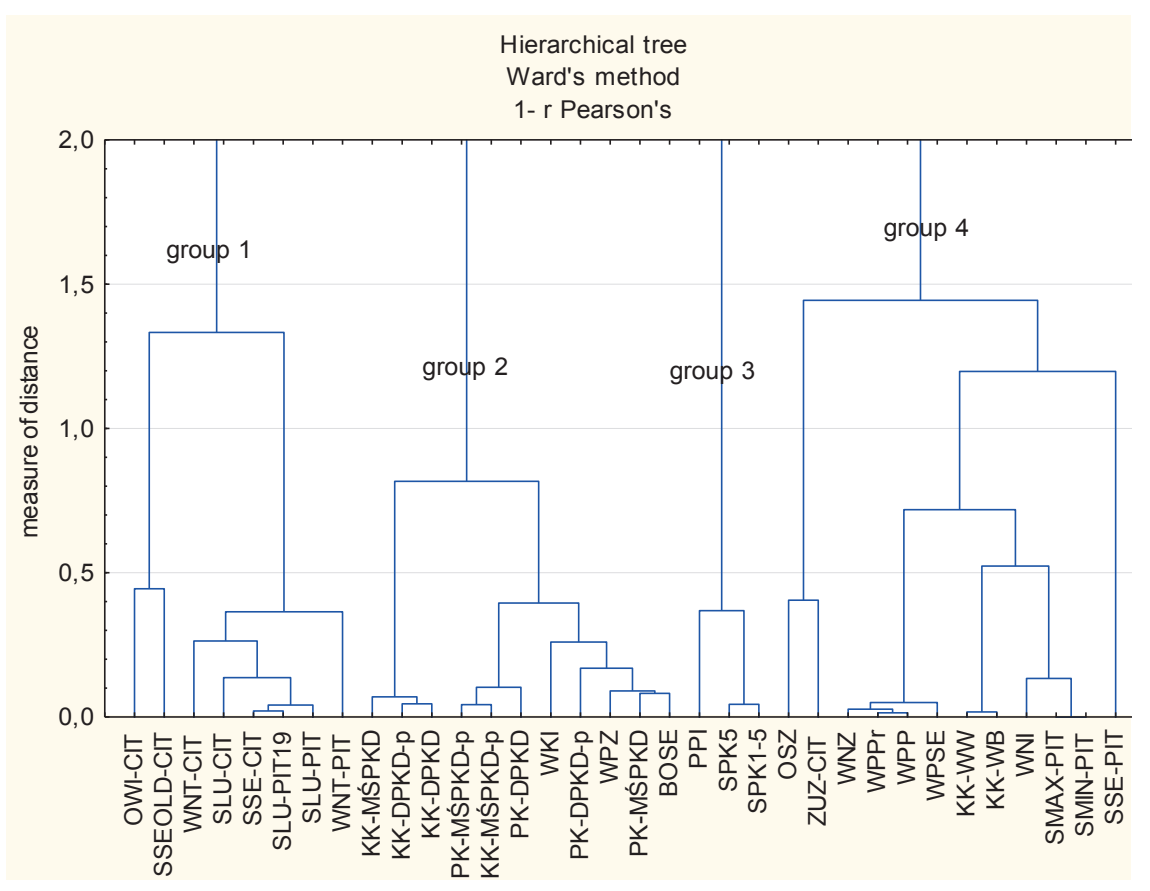

Figure 1. Cluster analysis - graph of hierarchical grouping variables

Four groups of variables are shown in Figure 1. There was no variable associated with the investments of MSEs, MEs, or LEs in either the second or third group. On the other hand, in the first group as well as in the fourth, most variables are related to the investments of MSEs, MEs, or LEs. Tax incentives were mainly in the first group. Moreover, almost all variables are significantly correlated with each other.

The next step of the analysis was a multidimensional scaling. It is used in order to reveal important hidden dimensions that allow us to explain the observed similarities or differences (distance) between variables (StatSoft 2014). All variables, including variables describing the level of investment spending, were selected for analysis. The standard configuration of Guttman-Lingoes was adopted as the initial configuration, and the process of estimating achieved convergence after 16 iterations. Figure 2 shows the result of the final configuration in two dimensions.

Based on the estimation results such as the stress factor (0.142), the coefficient of alienation (0.157), and the Shepard diagram, the obtained projection can be considered as an average. The average distance was to match the reconstituted final configuration to the actual distance (resulting from the distance matrix). 


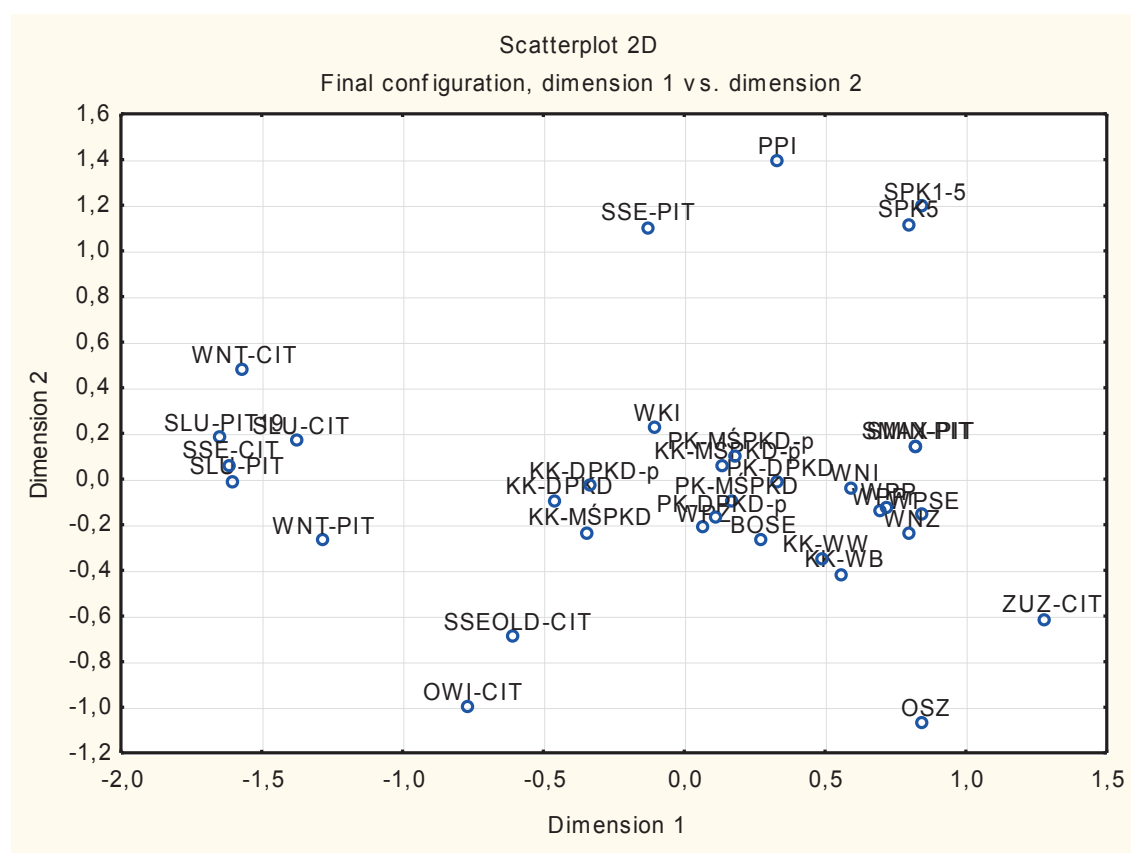

Figure 2. Multidimensional scaling - final configuration

However, Figure 2 shows that the variables form a number of groups similar to the cluster analysis. One group consists of some tax instruments. The other two groups include variables related to consumer confidence, business prosperity in the industry, and surveys conducted by the NBP on the situation of the credit market. The outliers are, for example, PPI, interest rates of loans (SPK1-5, SPK5), gross household savings (OSZ), and one of the fiscal incentives (ZUZ-CIT).

One of the essential elements of multidimensional scaling is to interpret the received final configuration dimensions. One can assume that Dimension 1 is a measure of the similarity of variables, like the correlation coefficient. It is more difficult to interpret Dimension 2. After some additional studies, it appears that the dimension shows a measure that is similar to the sum of the correlation coefficients of the variable with the others.

Both of these types of analysis were used to widen the possibilities of statistical inference. Analyses showed a relationship between the dependent variables and potential independent variables that allow us to group the potential independent variables, which makes it possible to attempt to build an econometric model.

Analyses were made with the Statistica program. 


\subsection{Building the econometric model}

The final stage of the statistical analysis was an attempt to build the econometric model with one equitation based on multiple regression. The potential independent variables were divided into groups using the previous analysis. The selection of variables that represent each group was made by the method of unweighted pair-group centroid. This method involves (for groups of more than two-elements) selection of the variable in which the sum of distances to the other variables in the group is the lowest. Based on Figure 1, it was found that:

- SLU-PIT from Group 1 was selected as an explanatory variable;

- WNZ from Group 4 was selected as an explanatory variable;

- there is no variable significantly correlated with the investments of MEs, MSEs, or LEs in Groups 2 and 3;

- variables SLU-PIT and WNZ are associated with both the investments of MSEs, MEs, and LEs.

Using multiple regression analysis, three econometric models with one equitation for each dependent variable was built. In the best model, the investments of MSEs were the dependent variable. The multiple correlation coefficient was $\mathrm{R}=0.923\left(\mathrm{R}^{2}=0.852\right)$. The condition of coincidence was met (Hellwig 1976):

$$
\operatorname{sign}(y(x j, y))=\operatorname{sign}(\beta j)
$$

where:

sign $(r(x j, y))$ - a sign of the correlation coefficient between the dependent and the explanatory variable

sign $(\beta j)$ - a sign of a beta coefficient in the econometric model for the explanatory variable.

Unfortunately, the beta coefficient of the variable WNZ was statistically insignificant - the significance level was $p \leq 0.05$. Under these circumstances, to create an econometric model seems pointless. Otherwise, the model with one dependent variable lead to almost the same conclusion as the calculation of the linear correlation between the investments of MSEs and the SLU-PIT (which, moreover, is almost identical [0.920] to the coefficient of multiple regression).

The other two models were characterized by both a lower coefficient R2 and the irrelevance of beta coefficients for both variables. 


\section{Conclusions}

The relationship between fiscal instruments and the investments of both small- and medium-sized enterprises as well as large companies in Poland has not been the main subject of research. Although some studies have been taken so far, no conclusive answers exist as of yet. In connection to this, the authors decided to analyze this area of research.

The statistical analysis revealed that there is a significant relationship between the level of investment in micro, small, and medium-sized enterprises and the majority of tax instruments. This supports hypothesis H1 in some part. However, the results suggest that the smaller the enterprise, the more stronger relationship with fiscal incentives exists. There are tax instruments that are correlated with all size of enterprises. This includes settlement of losses from previous years according to both the flat tax and general, progressive tax scale under PIT and special economic zones under CIT. Moreover, the relationship between these instruments and the investments of MSEs is stronger than for MEs and LEs. This supports hypothesis $\mathrm{H} 2$.

The authors also make a comparison with other factors that should influence the investments of enterprises. It turns out that there is a negative relationship between the instruments and the indicators of consumer confidence and business prosperity, particularly for medium- and large-sized companies. Moreover, there are outliers that include PPI, interest rates of loans, and gross households savings. In connection to this, hypothesis $\mathrm{H} 3$ should be rejected.

The authors also tried to build an econometric model, but it was impossible. Nevertheless, the area of research undertaken by the authors needs more studies. It should be connected with (among others) an attempt to estimate the deadweight effect of fiscal incentives.

\section{References}

[1] Analiza korzyści i ograniczeń przy zastosowaniu inżynierii finansowej jako instrumentu wsparcia projektów inwestycyjnych z zakresu energetyki. Raport końcowy (2012), Warszawa: Ministerstwo Gospodarki.

[2] Baghana, R. and Mohnen, P. (2009) 'Effectiveness of R\&D tax incentives in small and large enterprises in Québec', Small Business Economics, vol. 33, no. 1, pp. 91-107.

[3] Begg, D., Fischer, S. and Dornbusch, R. (2005), Economics, Eighth edition, New York: McGraw-Hill Education.

[4] Bertoni, F., Colombo, M.G. and Grilli, L. (2011) 'Venture capital financing and the growth of high-tech start-ups: Disentangling treatment from selection effects', Research Policy, vol. 40, no. 7, pp. 1028-1043. 
[5] Boocock, G. and Shariff, M.N.M. (2005) 'Measuring the effectiveness of credit guarantee schemes evidence from Malaysia', International Small Business Journal, vol. 23, no. 4, pp. 427-454.

[6] Chen, J. (2006) 'Development of Chinese small and medium-sized enterprises', Journal of Small Business and Enterprise Development, vol. 13, no. 2 , pp. 140-147.

[7] Denis, D.J. (2004) 'Entrepreneurial finance: an overview of the issues and evidence', Journal of Corporate Finance, vol. 10, no. 2, pp. 301-326.

[8] Duda, J. (2013) 'The role of bank credits in investment financing of the small and medium-sized enterprise sector in Poland', Managerial Economics, vol. 13, no. 1, pp. 7-20.

[9] Główny Urząd Statystyczny, [Online] Available: http://stat.gov.pl/obszary-tematyczne/koniunktura/ [30 June 2016].

[10] Główny Urząd Statystyczny, [Online] Available: http://stat.gov.pl/obszary-tematyczne/ceny-handel/ceny/ [30 June 2016].

[11] Gołębiowski, G. (2009) Znaczenie polityki finansowej i czynników społeczno-kulturowych dla rozwoju małych i średnich przedsiębiorstw w Polsce, Warszawa: Szkoła Główna Handlowa.

[12] Goolsbee, A. (1997) 'Investment tax incentives, prices, and the supply of capital goods', Working Paper 6192, Cambridge: National Bureau of Economic Research.

[13] Hellwig, Z. (1976) 'Przechodniość relacji skorelowania zmiennych losowych i płynące stąd wnioski ekonometryczne', Przegląd Statystyczny, no. 23, pp. 3-20.

[14] Hendricks, K., Amit, R. and Whistler, D. (1997) Business taxation of small and medium-sized enterprises in Canada, Vancouver: Department of Finance (Canada), Technical Committee on Business Taxation.

[15] Karafolas, S., Woźniak, M. (2014a) 'Loan Guarantee Schemes: Private and Public Examples', World Academy of Science, Engineering and Technology, International Journal of Social, Behavioral, Educational, Economic, Business and Industrial Engineering, vol. 8, no. 5, pp. 1291-1297.

[16] Karafolas, S. and Woźniak, M. (2014b) 'Financial Sources and Instruments for Public Grants and Financial Facilities of SMEs in EU', World Academy of Science, Engineering and Technology, International Journal of Social, Behavioral, Educational, Economic, Business and Industrial Engineering, vol. 8, no. 8, pp. 2582-2588.

[17] Karlan, D.S. (2007) 'Social connections and group banking', The Economic Journal, vol. 117 , no. 517, pp. 52-84.

[18] Krugman, P. and Wells, R. (2012) Makroekonomia, Warszawa: PWN.

[19] Matejun, M. (2003) 'Ocena systemu wspomagania małych i średnich przedsiębiorstw w aglomeracji łódzkiej', Zeszyty Naukowe. Organizacja i Zarządzanie/Politechnika Łódzka, vol. 38, no. 937, pp. 29-44. 
[20] Matejun, M. (2005) 'Ocena systemu wspomagania małych i średnich przedsiębiorstw przez przedstawicieli instytucji działających w otoczeniu biznesu', Zeszyty Naukowe. Organizacja i Zarządzanie/Politechnika Lódzka, vol. 41, no. 958, pp. 49-60.

[21] Mikropożyczki w Polsce. Raport (2013), Warszawa: Związek Firm Pożyczkowych.

[22] Ministerstwo Finansów, [Online] Available: http://www.finanse.mf.gov.pl/cit/ statystyki, http://www.finanse.mf.gov.pl/pit/statystyki [30 June 2016].

[23] Mintz, J.M. (1990) 'Corporate tax holidays and investment', The World Bank Economic Review, no. 4(1), pp. 81-102.

[24] Muhammad, M.Z., Char, A.K., bin Yasoa, M.R. and Hassan, Z. (2010) 'Small and medium enterprises (SMEs) competing in the global business environment: A case of Malaysia', International Business Research, vol. 3, no. 1, pp. 66-75.

[25] Narodowy Bank Polski, [Online] Available: http://www.nbp.pl/home.aspx?c=/ ascx/koniunktura_prezentacja.ascx [30 June 2016].

[26] Narodowy Bank Polski, [Online] Available: http://www.nbp.pl/home.aspx?f=/ statystyka/pieniezna_i_bankowa/oprocentowanie_n.html [30 June 2016].

[27] Narodowy Bank Polski, [Online] Available: http://www.nbp.pl/home.aspx?f=/ systemfinansowy/kredytowy.html [30 June 2016].

[28] Newman, A., Schwarz, S. and Borgia, D. (2014) 'How does microfinance enhance entrepreneurial outcomes in emerging economies? The mediating mechanisms of psychological and social capital', International Small Business Journal, vol. 32, no. 2, pp. 158-179.

[29] Norrman, C. and Bager-Sjögren, L. (2010) 'Entrepreneurship policy to support new innovative ventures: Is it effective?', International Small Business Journal, vol. 28, no. 6, pp. 602-619.

[30] Ortega-Argilés, R., Vivarelli, M. and Voigt, P. (2009) 'R\&D in SMEs: a paradox?', Small Business Economics, vol. 33, no. 1, pp. 3-11.

[31] Peszko, A. (2014) 'Micro-, small-, and medium-sized enterprises using structural funds', Managerial Economics, vol. 15, no. 1, pp. 97-106.

[32] Pokorski, J. (ed.) (2010) Ocena instrumentów wsparcia bezpośredniego przedsiębiorstw: podsumowanie wyników ewaluacji wybranych Działań SPO WKP, Warszawa: Polska Agencja Rozwoju Przedsiębiorczości.

[33] Pokorski, J. (ed.) (2011) Towards Innovative Economy. Effects of Grants to Enterprises in Poland, Warszawa: Polish Agency for Enterprise Development.

[34] Preferencje podatkowe w Polsce (2014), nr 5, Warszawa: Ministerstwo Finansów.

[35] Raport o pomocy publicznej w Polsce udzielonej przedsiębiorcom w 2014 roku (2015), Warszawa: Urząd Ochrony Konkurencji i Konsumentów.

[36] Riding, A.L. and Haines, G. (2001) 'Loan guarantees: Costs of default and benefits to small firms', Journal of Business Venturing, vol. 16, no. 6, pp. 595-612. 
[37] Rocznik statystyczny przemysłu (2007, 2008, 2009, 2010, 2011, 2012, 2013, 2014), Warszawa: Główny Urząd Statystyczny, Zakład Wydawnictw Statystycznych.

[38] Rocznik statystyczny Rzeczpospolitej Polskiej (2007, 2008, 2009, 2010, 2011, 2012, 2013, 2014, 2015), Warszawa: Główny Urząd Statystyczny, Zakład Wydawnictw Statystycznych.

[39] StatSoft, Inc. (2014) STATISTICA (data analysis software system), version 12, [Online] Available: www.statsoft.com [30 June 2016].

[40] Wach, K. (2008) Regionalne otoczenie małych i średnich przedsiębiorstw, Kraków: Wydawnictwo Uniwersytetu Ekonomicznego.

[41] Ward, J. (1963) 'Hierarchical grouping to optimize an objective function', Journal of the American Statistical Association, vol. 58, no. 301, pp. 236-244.

[42] Woźniak, M. (2007) 'Możliwości finansowania rozwoju małych i średnich przedsiębiorstw kredytem bankowym', in Preisner, L. (ed.) Finansowe aspekty transformacji gospodarki w Polsce, Kraków: Uczelniane Wydawnictwa Naukowo-Dydaktyczne AGH, pp. 127-135.

[43] Woźniak, M. (2011) 'Ocena znaczenia finansowych instrumentów wspierania stosowanych w Polsce i innych krajach Unii Europejskiej’, Przegląd Organizacji, no. 7-8, pp. 58-61.

[44] Woźniak, M. (2012) System wspierania małych i średnich przedsiębiorstw w Polsce, Kraków: Wydawnictwa AGH.

[45] Wyszkowski, A. (2010) 'Koncepcja tax expenditures w systemie podatkowym', Gospodarka Narodowa, no. 9, pp. 65-82.

[46] Zbroińska, B. (2006) Aktywność podatkowa w zarządzaniu przedsiębiorstwem, Kielce: Wydawnictwo Akademii Świętokrzyskiej.

[47] Zbroińska, B. (2008) 'Pozafiskalne funkcje podatku dochodowego w praktyce gospodarczej', Gospodarka Narodowa, no. 1-2, pp. 91-110. 